\title{
Stakeholders' Perception of the Triggering Mechanisms and Determinants of Flooding in Limbe, South West Region of Cameroon
}

\author{
Robert Njilla Mengnjo Ngalim ${ }^{1 *}$ and Simbo Terence Nunyui ${ }^{2}$ \\ ${ }^{1}$ Department of Geography and Planning, Faculty of Arts, The University of Bamenda, P.O. Box 39, \\ Bambili, North West Region of Cameroon, Cameroon. \\ ${ }^{2}$ Department of Geography, Faculty of Social and Management Sciences, University of Buea, \\ P.O. Box 63, Buea, South West Region of Cameroon, Cameroon.
}

\begin{abstract}
Authors' contributions
This work was carried out in collaboration between both authors. Both authors RNMN and STN designed the study, performed the statistical analysis, wrote the protocol and wrote the first draft of the manuscript. Both authors participated in data collection and analyses of the study. Both authors read and approved the final manuscript.
\end{abstract}

Article Information

DOI: $10.9734 / A J G R / 2020 / v 3 i 430113$ Editor(s):

(1) Dr. Armando García Chiang, Universidad Autónoma Metropolitana, México. Reviewers:

(1) Luz Angela Martinez Martinez, Universidad Autónoma de Occidente, Colombia.

(2) Mahfuzul Haque, Bangladesh University of Professionals (BUP), Bangladesh. Complete Peer review History: http://www.sdiarticle4.com/review-history/60755

\begin{abstract}
The study investigates stakeholders' perception of the triggering mechanisms and determinants of flooding episodes in Limbe. Primary data were collected using questionnaires administered in ten (10) study sites. Interviews were conducted, field observation and measurement carried out on the drain sizes, height and duration of flooding. Secondary data were obtained from text books and journals. Data were analysed using qualitative and quantitative methods. Findings revealed that a plethora of triggering mechanisms of flooding were identified and analysed under natural and anthropogenic factors. However, of all these factors, prolonged rainfall and the inadequacy and narrowness of drains were perceived to be the most important triggering mechanisms of flooding in Limbe. The study concluded that flooding is a hazard that has been plaguing the city of Limbe for close to two decades and therefore needs appropriate flood control strategies to be employed to effectively control flooding since it cannot be completely stopped in some parts of Limbe. Since the
\end{abstract}


inadequacy / narrowness of drains was perceived as the most important triggering mechanism of flooding in Limbe, it was recommended that wide drains be constructed in all the flood prone and flood affected areas in the city of Limbe.

Keywords: Stakeholders' perception; triggering mechanisms; determinants; flooding episodes; Limbe; Cameroon.

\section{INTRODUCTION}

Floods are natural events which mainly happen when the river catchment, that is the area of land that feeds water into the river and the streams that flow into the main river receives greater than usual amounts of water for example through rainfall or melting snow. Floods impact an estimated $520+$ million people per year worldwide, resulting in approximately 25,000 annual deaths, extensive homelessness, disaster-induced disease, crop and livestock damage and other serious harm. The greatest potential flood hazard is in Asia. Every year for the past two decades, more than 400 million people on average have been directly exposed to a flood. Between 1987 and 1997, 44\% of all flood disasters worldwide affected Asia, claiming 228,000 lives (roughly $93 \%$ of all floodrelated deaths worldwide). Economic losses in the region in that decade totalled US $\$ 136$ billion [1].

The study seeks to establish the perception of triggering mechanisms of flooding in the different localities and across different stakeholders in Limbe and how they influence the flood management decisions of Limbe city. Limbe is a coastal city with approximately $50.5 \mathrm{~km}$ of coastline. This town has experienced persistent floods over the years with one of the worst being in June 2001, taking lives, rendering over 2,000 people homeless, and destroying properties and social amenities such as roads and telephone lines worth millions of CFA francs $[2,3,4]$. The causes of flood disasters in this region vary from one year to another, and this has shaped people's perception of the triggering mechanism of the disaster. Most human settlements in Limbe are around the coast, with few settlements situated above $200 \mathrm{~m}$. Low-lying areas adjacent to the sea include Mbonjo, Motowoh, Down Beach, Bota-Island and a host of other villages on the west coast of the city. Areas around the city of Limbe with remarkable hills include Towe, Mile Two, Coconut Island, Mabeta New Layout and Ambas Bay. Floods are a common phenomenon in the city of Limbe. All settlements along the Djenguele River basin i.e. Animal
Farms, Cassava Farms, Lumpsum, Church Street, New Town and Down Beach have suffered from persistent flooding over the years. At Mawoh Bridge during the raining seasons, water usually rises to a height of about $2.6 \mathrm{~m}$. The width of the river bed that was formerly just a small channel has now increased to $27 \mathrm{~m}$ due to a series of flood events. The number of hours of flood causes serious impact in different localities in the city of Limbe. In August 2005, a series of inundations occurred around the city of Limbe lasting for several hours and disrupting traffic. The urban poor are the most affected by flood because they live in flood prone areas where land is relatively less expensive. Rainstorms have been an important contributor to floods in the city of Limbe. All recorded floods in Cameroon within the last 18 years have occurred between the months of June and September, which are the rainiest months of the year $[2,5,6]$. Some people thus perceive heavy rains as being the cause of the flood disasters. The process of urbanization which is usually accompanied new infrastructures, construction of roads and expansion of the city of Limbe does not take into consideration adequate drainage patterns to contain runoff. Despite the existing water channels, drains were constructed without considering the maximum volume of water expected to flow through them during rainy periods. Thus, during the rainiest months, settlements along Djenguele River and Limbe River suffer from inundation causing the destruction of properties and loss of human lives. Another school of thought perceives urbanization and the poor drainage conditions as being the trigger mechanism of the floods. The manner in which the flood disasters have been handled over the years by the management authorities of the Limbe city has largely reflected their perception of triggering mechanisms of the floods. This partly accounts for why the floods have not been adequately handled. The main question is: "What are the perceptions of the various stakeholders on the triggering mechanisms and determinants of flooding in Limbe? The study hypothesized that: Flooding in Limbe is perceived to be triggered by prolonged rainfall. 


\section{MATERIALS AND METHODS}

\subsection{Study Area}

Limbe is located between latitudes $3^{\circ} 31^{1}$ and $4^{\circ} 15^{1}$ north of the equator, and longitudes $8^{\circ} 15^{1}$ and $9^{\circ} 35^{1}$ east of the Greenwich meridian. Limbe is bounded to the north by Mt. Cameroon, east by Tiko sub-division, south by the Atlantic Ocean and west by Idenau (Fig. 1). According to the Limbe Municipality Report of 2016, the city covers a total land surface area of about $548 \mathrm{~km}^{2}$ today. Ten sites were selected for study, as follows: Mbonjo, Down Beach, Dockyard, Clerks Quarters, Church Street, Lumpsum, Cassava Farms, Mawoh Quarter, Motowoh Quarter and Mabeta New Layout.

Site 1 (Mbonjo): This site was chosen because of the nature of its relief and drainage conditions. It is a low lying area located around a flood plain and reclaimed wetlands where most of the houses have been constructed. This makes the area very liable to flooding. The soils in Mbonjo are clay soils which have a low infiltration capacity which influences flooding in the area.

Site 2 (Down Beach): Down beach is a low-lying area located along the coast line of the Atlantic Ocean. Its proximity to the Atlantic Ocean increases flooding risk in the area. This vicinity is also drained by the Djenguele River which during most parts of the rainy season over flows it banks leading to flooding in the area. It is based on this criterion that this site was chosen for study.

Site 3 (Dock Yard): Dock yard is a low lying area located along the coast line of the Atlantic Ocean. This site was chosen for study due to the drainage conditions of the area. The settlement was constructed on reclaimed mangrove which experiences periodic flooding during periods of high tides. This area is also drained by the Djenguele River whose channel is unconfined around the Dock yard area.

Site 4 (Clerks Quarters): Site 4 was chosen because of the nature of its relief and drainage conditions. It is a low lying area located around a flood plain of the Djenguele River and reclaimed wetlands where most of the houses have been constructed. This makes the area very liable to flooding. The soils in Clerks quarters are clay soils which have a low infiltration capacity and a high water table which influences flooding in the area.
Site 5 (Church Street): Site 4 was chosen because it has a low lying relief which makes the area easily flooded. This is couples with a high water table and the non-permeability of the soils. Church Street is also located along a flood plain where houses have been built quite close to the rivers bank. This makes the area conducive for flooding.

Site 6 (Lumpsum): This quarter is located at the foot of the animal farms hill. All the runoff from this hill flows to Lumpsum quarter and causes flooding. The water table is also very high especially during the rainy season with occasional springs developing. The area is also poorly drained.

Site 7 (Cassava Farms): This quarter is located at the foot of the animal farms hill. All the runoff from this hill goes down to Cassava farms and causes flooding. The area is also poorly drained and coupled with the absence of drains, flooding is bound to occur especially during the rainy season.

Site 8 (Mawoh Quarter): This quarter is poorly drained with no drainage channel. Houses have also been constructed on the river course which provokes flooding during the rainy season.

Site 9 (Motowoh Quarter): This site was chosen because it is poorly drained with no drainage channel. Houses have also been constructed on the river course which provokes flooding during the rainy season. It also has a high water table.

Site 10 (Mabeta New Layout): This was chosen because it is poorly drained with no drainage channel. Houses have also been constructed on the river course which provokes flooding during the rainy season.

\subsection{Data Collection Methods}

The descriptive and analytical survey methods were employed in this study. Primary and secondary data collection techniques were used in this study.

\subsection{Primary Data}

Primary data were obtained through field observation, questionnaires, interviews and cartographic techniques. A questionnaire comprised of closed and open-ended questions were administered to different stakeholders such as the local planning authorities of the flood affected areas, street vendors and the 
indigenous population of the area to sample their perceptions on the triggering mechanisms of floods in their respective quarters. Interviews were also conducted to the municipal authorities and to those living in flood prone areas. Photographs were also be taken to show the magnitude of floods in different quarters in the city of Limbe, the low nature of some bridges influence flooding and the role of anthropogenic activities such as encroachment into wetlands have contributed to flooding. Field measurements were carried out on the various drains within the city of Limbe. The depth, width and the effectiveness of the drains in handling runoff were calculated. The flood heights for the recent floods were measured.

\subsection{Secondary Data}

Secondary data were obtained from relevant published and unpublished journals, articles, textbook. Magazines, text, bulletins reports and local council publications. Some base maps were updated and modified.

\subsection{Data Collection Procedure and Techniques}

The data needed to answer the question on perceived triggering mechanisms of floods include the drain sizes: depth and width; and data to show the worst affected areas. The data was collected through field observation of the flood prone areas. Interviews were also conducted with those living in flood prone areas and official concerned with the distribution of relief aid. Questionnaires were administered to those living in the flood prone areas. To this effect, a total of 150 questionnaires were administered containing both closed and open ended questions.

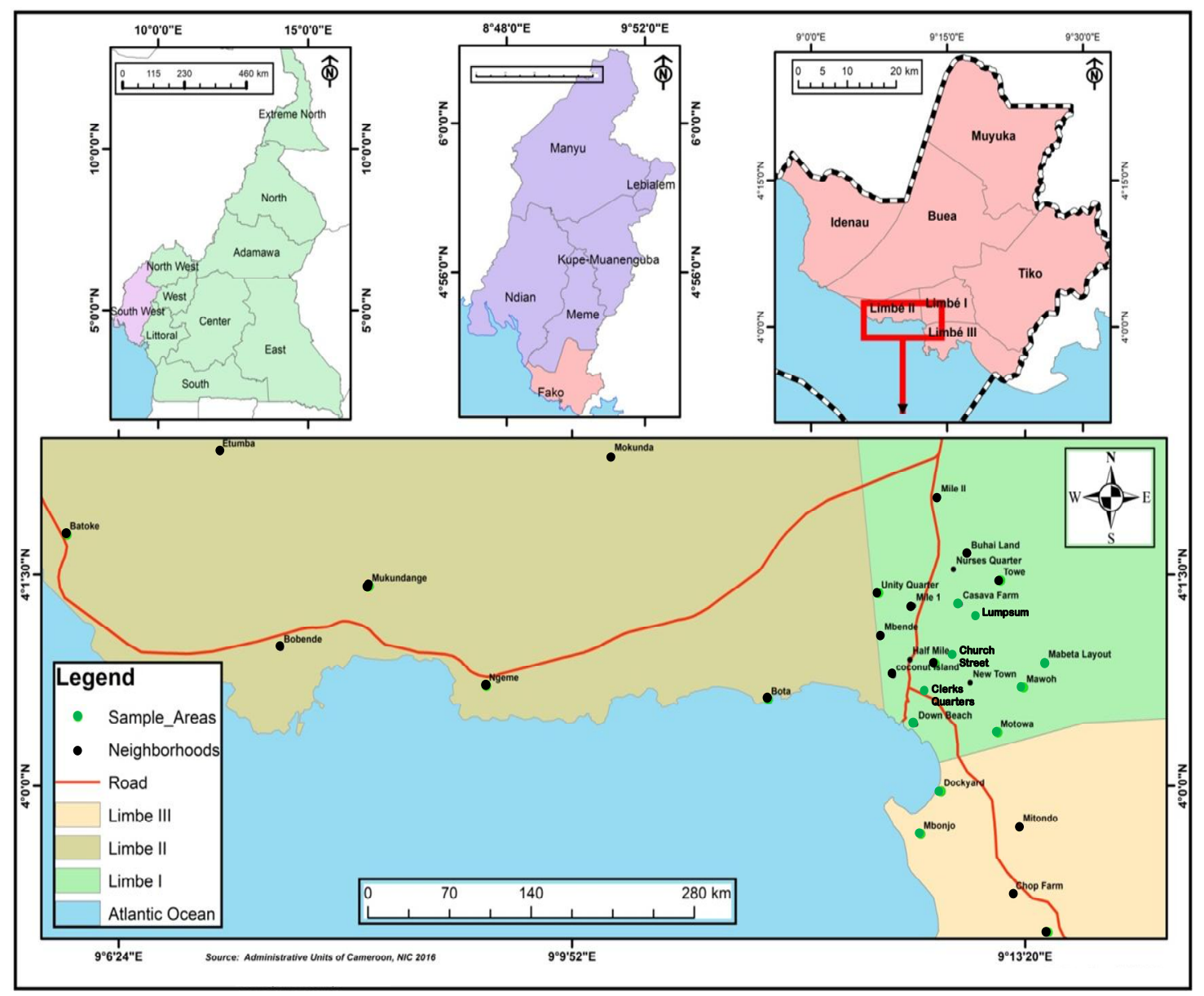

Fig. 1. Map showing geographical location of the study area Source: Adapted from the Map of Limbe, NIC (2016) 


\subsection{Data Treatment and Analysis}

The data were treated using two techniques, namely, descriptive and statistical analysis. The Chi Square Analysis was used to test the hypothesis. Descriptive analysis was guided by the use of frequencies and percentages. Another important technique of data analysis for this research is cartographic analysis. This constitutes the use of maps to depict the study area, relief, hydrographic network and other phenomena under study. The maps were updated from base maps. Photographs were also used to depict the phenomena over time.

\section{PRESENTATION OF FINDINGS}

The first section presents a map depicting the major flood affected areas in Limbe (Fig. 2). Areas such as Lumpsum, Cassava Farms, Church Street, Clerks Quarters, Mawoh Quarters, Motowoh Quarters, Down Beach, Mbonjo and Dockyard are the most affected by flooding. The medium risk areas include Bimbia, Limbe I, especially Moviokulu
Limbe III particularly Camps Three and Four, and Batoke.

\subsection{Perception Mechanisms Different Stakeholders}

The different professions were civil servants, students, technicians, traders, street vendors and lay persons. Most of the town planners perceived that flooding in Limbe is triggered by factors such as inadequate drains, uncontrolled waste disposal, reclamation and drainage of wetlands, human encroachment on river channel, nature of rainfall and poor drainage conditions. A greater proportion of administrators were of the opinion that flooding is triggered by factors like inadequate drains, poor urban governance, uncontrolled waste disposal and nature of rainfall. They however identified other factors such as topography, soil type, deforestation and increasing population were perceived to be minor flood trigger mechanisms of flooding in Limbe. Table 1 shows the perception of triggering mechanisms of flooding from different categories of respondents in the study sites.

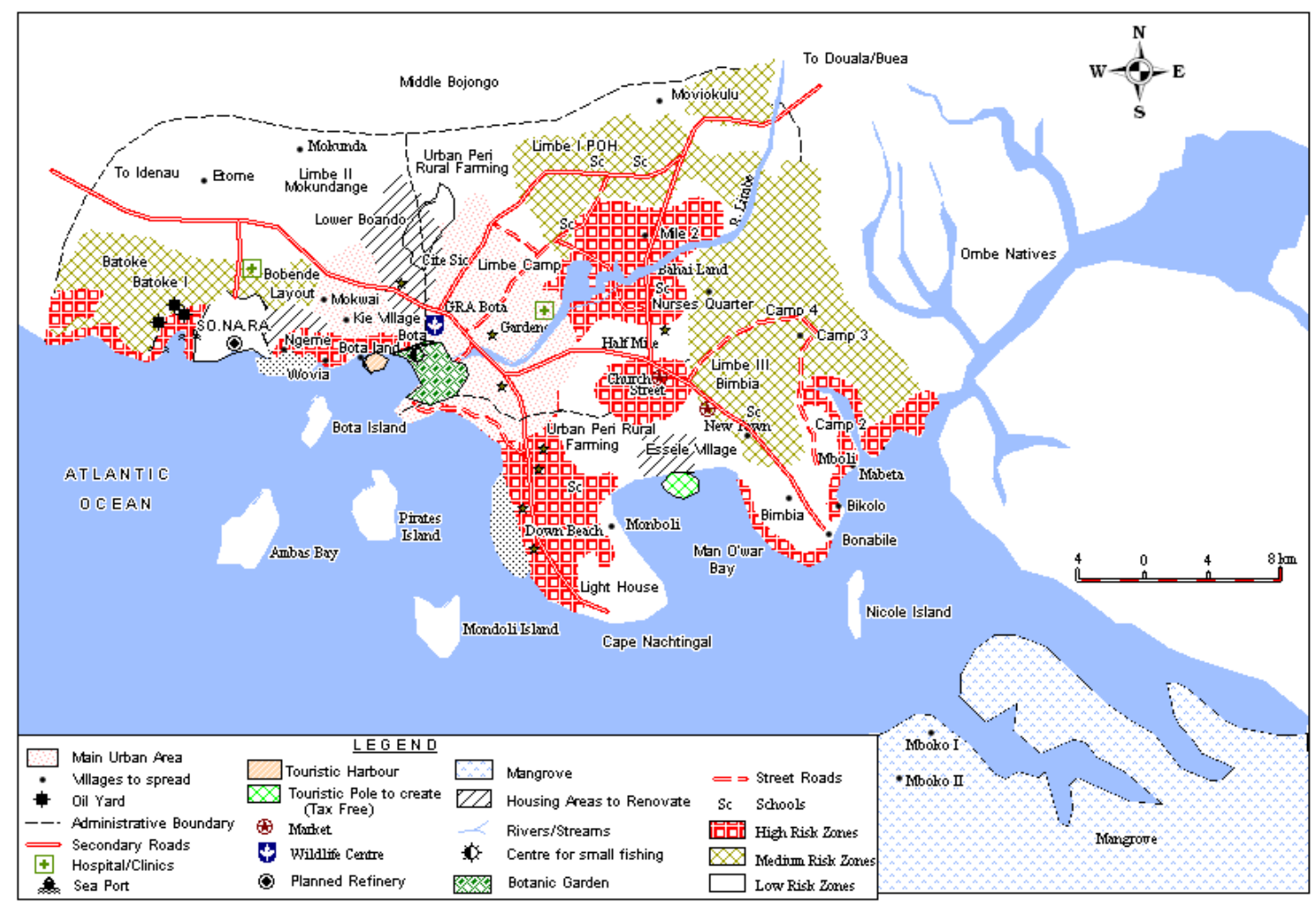

Fig. 2. Map depicting the flood affected areas in Limbe Source: Adapted from the Map of Limbe, NIC (2016) 
Njilla and Simbo; AJGR, 3(4): 17-34, 2020; Article no.AJGR.60755

Table 1. Perception of triggering mechanisms of flooding by different stakeholders

\begin{tabular}{|c|c|c|c|c|c|c|c|}
\hline Factors & Civil servants & Students & Technicians & Traders & Lay persons & $\begin{array}{l}\text { Street } \\
\text { vendors }\end{array}$ & $\begin{array}{l}\text { Total / } \\
\text { Average }\end{array}$ \\
\hline Nature of topography & $9(8.50 \%)$ & $11(10.38 \%)$ & $20(18.87 \%)$ & $50(47.17 \%)$ & $10(9.43 \%)$ & $6(5.66 \%)$ & $106(16.67 \%)$ \\
\hline Nature of rainfall & $25(18.66 \%)$ & $22(16.42 \%)$ & $20(14.93 \%)$ & $30(14.93 \%)$ & $26(19.40 \%)$ & $11(8.21 \%)$ & $134(16.67 \%)$ \\
\hline Soil type & $20(25.97 \%)$ & $18(23.38 \%)$ & $12(15.58 \%)$ & $9(11.69 \%)$ & $12(15.58 \%)$ & $6(7.80 \%)$ & $77(16.67 \%)$ \\
\hline Drainage conditions & $25(28.09 \%)$ & $13(14.60 \%)$ & $8(8.99 \%)$ & $10(11.24 \%)$ & $15(16.85 \%)$ & $18(20.22 \%)$ & $89(16.67 \%)$ \\
\hline Deforestation & $9(16.36 \%)$ & $15(27.27 \%)$ & $10(18.18 \%)$ & $8(14.55 \%)$ & $7(12.72 \%)$ & $6(10.91 \%)$ & $55(16.67 \%)$ \\
\hline Increasing population & $20(18.52 \%)$ & $25(23.15 \%)$ & $15(13.89 \%)$ & $16(14.81 \%)$ & $30(27.78 \%)$ & $2(1.85 \%)$ & $108(16.67 \%)$ \\
\hline $\begin{array}{l}\text { Human encroachment on river } \\
\text { channel }\end{array}$ & $25(32.47 \%)$ & $12(15.58 \%)$ & $8(10.39 \%)$ & $9(11.69 \%)$ & $15(19.48 \%)$ & $8(10.39 \%)$ & $77(16.67 \%)$ \\
\hline $\begin{array}{l}\text { Reclamation and draining of } \\
\text { wetlands }\end{array}$ & $30(26.32 \%)$ & $21(18.42 \%)$ & $10(8.77 \%)$ & $13(11.40 \%)$ & $31(27.19 \%)$ & $9(7.89 \%)$ & $114(16.68 \%)$ \\
\hline $\begin{array}{l}\text { Inadequate/narrowness of } \\
\text { drains }\end{array}$ & $30(21.28 \%)$ & $20(14.18 \%)$ & $12(8.51 \%)$ & $20(14.18 \%)$ & $35(24.82 \%)$ & $22(15.60 \%$ & $141(16.68 \%)$ \\
\hline Uncontrolled waste disposal & $30(23.81 \%)$ & $21(16.67 \%)$ & $25(19.84 \%)$ & $20(15.87 \%)$ & $18(14.29 \%)$ & $12(9.52 \%)$ & $126(16.67 \%)$ \\
\hline Poor urban governance & $21(15.33 \%)$ & $22(16.06 \%)$ & $24(17.52 \%)$ & $25(18.25 \%)$ & $25(18.25 \%)$ & $20(14.60 \%)$ & $137(16.67 \%)$ \\
\hline Total / Average & $\begin{array}{l}235.31 \\
(21.39 \%) \\
\end{array}$ & $\begin{array}{l}196.11 \\
(17.83 \%)\end{array}$ & $\begin{array}{l}155.47 \\
(14.13 \%)\end{array}$ & $\begin{array}{l}193.24 \\
(17.57 \%) \\
\end{array}$ & $\begin{array}{l}205.79 \\
(18.71 \%)\end{array}$ & $\begin{array}{l}112.65 \\
(10.24 \%)\end{array}$ & $\begin{array}{l}100.00 \\
(16.67 \%)\end{array}$ \\
\hline
\end{tabular}


The general trend from the table indicates that a greater proportion of the respondents perceived inadequacy / narrowness of drains as the most important triggering mechanism of flooding in Limbe. Other important factors included poor urban governance, uncontrolled waste disposal, reclamation and draining of wetlands, and natures of rainfall. The factors such as soil type, drainage conditions, human encroachment on the river channel were perceived to be trigger mechanisms but of a lesser extent.

Most traders perceived topography, rainfall and poor urban governance as the main triggering mechanisms. This is because according to them, these factors play an important role provoking flooding as there is high and reliable rainfall almost all year round, the nature of topography around the market area is undulation and the fact that this area is poorly planned makes them to perceive these factors as the trigger mechanisms of flooding. Therefore, there are two major triggers of floods in the city of Limbe: the anthropogenic (human) and physical (natural) triggers.

Statistics on Table 1 reveal that the different categories of respondents generally had a low perception about the triggering mechanisms of flooding scoring an average of $16.65 \%$. However the civil servants scored the highest percentage in this category of $21.39 \%$, followed by lay persons (commoners) with $18.71 \%$, students with $17.83 \%$ and traders with $17.57 \%$. Technicians and street vendors scored the least with $14.13 \%$ and $10.24 \%$ respectively. Furthermore, the civil servants, who responded to the questionnaires, perceived flooding to be triggered by nature of rainfall, drainage conditions, inadequacy of drains, uncontrolled waste disposal and reclamation, and draining of wetlands. The student population sampled perceived flooding to be triggered natures of rainfall, poor drainage, inadequacy of drains and uncontrolled solid waste disposal. The group of lay people surveyed, perceived flooding to be triggered by factors such as nature of rainfall, inadequate/narrowness of drains and poor urban governance. Finally, the table indicates that, factors such as inadequacy/narrowness of drains, poor urban governance, uncontrolled waste disposal and rainfall were perceived by respondents as the most important trigger mechanisms of flooding; while other factors such as soil type, deforestation, and human encroachment on river channel were perceived to be triggers of flooding in Limbe.

\subsection{Perception Mechanisms Stakeholders in the Different Study Sites}

The results indicate that the respondents' perception of the triggering mechanisms of flooding consisted of both natural and anthropogenic factors. The natural factors were the nature of topography, nature of rainfall, soil type and drainage conditions. The anthropogenic factors on the other hand included: increasing population, deforestation, human encroachment on river channel, inadequacy / narrowness of drains, reclamation and draining of wetlands, uncontrolled waste disposal and poor urban governance. The Perception of trigger mechanisms of flooding in the different study sites is presented on Table 2 .

Four (04) physical factors were considered to be the major triggers of flooding hazards in the ten (10) sampled locations in Limbe city. These include: the nature of rainfall (perceived by $34.66 \%)$ drainage conditions (41.33\%), topography $(34.66 \%)$ and the soil type $(6.67 \%)$. This therefore means that the majority of the population of Limbe city no longer perceive the physical nature of the environment to be the major triggering mechanisms of flowing in Limbe, since they are adapting to it. On the other hand, eight (08) human or anthropogenic factors were considered to be the major triggers of flooding hazards in the ten sampled locations in Limbe city. Among these are, reclamation and draining of wetlands $(90.67 \%)$, increasing population (59.33\%), human encroachment on river channels $(44.66 \%)$ and inadequate or narrowness of the runoff channels or storm drains $(42.00 \%)$. This is true because in recent years, Limbe city has witnessed an astronomical increase in population leading to an increase in the demand for land notably for multifarious human activities.

Respondents' perception of trigger mechanism of flooding in the different study sites have been analysed under natural and anthropogenic factors.

\subsection{Natural (Physical) Factors}

The results of the study revealed that respondents perceive the following physical factors as triggering mechanisms of flooding in the city of Limbe; nature of topography, nature of rainfall, soil type and drainage conditions. 


\subsubsection{Nature of rainfall}

The nature of rainfall is also perceived to be responsible for flooding in some areas. The climate is humid firstly because of its latitudinal location; $3^{\circ} \mathrm{N}$ and its proximity to the Atlantic Ocean. The rainy season usually lasts from midMarch to early November. Average annual rainfall is close to $4000 \mathrm{~mm}$ annually associated with a mean annual temperature of $26-27^{\circ} \mathrm{C}$. Thus precipitation is associated with convection uplift, topographic effects and proximity to the ocean which brings about heavy rainfall, contributing to flooding. The year 2001 for instance recorded one of the highest rainfall intensities which accounted for the severe nature of flooding during that year. Rainfall is perceived by the inhabitants of all the flood affected areas as the major trigger of flooding. Table 2 indicates that $73.33 \%$ of the respondents in Lumpsum, $66.66 \%$ in Cassava Farms, $53.33 \%$ in Church Street and Mawoh, perceive the nature of rainfall to be the main trigger of flooding in these quarters. The 2010 floods of June to August which affected these sites were perceived to be triggered by nature of rainfall.
Table 3 indicates the average flood heights and their duration for the different quarters in Limbe for 2010 and 2019. Consistently, the town has witnessed an increasing trend in the height of floods as well as the duration of flood events in hours. This is caused by a plethora of factors including the nature of the topography, increasing population, expanding settlements, depletion of storm drains and chocking of storm drains with debris particularly non-biodegradable wastes. For example, quarters like Cassava Farms and Motowoh have the highest flood height being the areas with severe flooding. The reason for this is as a result of the fact that rainfall during this year was intense leading to a high discharge or runoff which accounts for the severity of the floods. Looking at the trend above in other localities such as Church Street, Down Beach, Mbonjo, flooding is perceived to be caused by or triggered by prolonged rainfall.

\subsubsection{Drainage conditions}

Fig. 3 shows the regularly flooded rivers and streams in the city of Limbe.

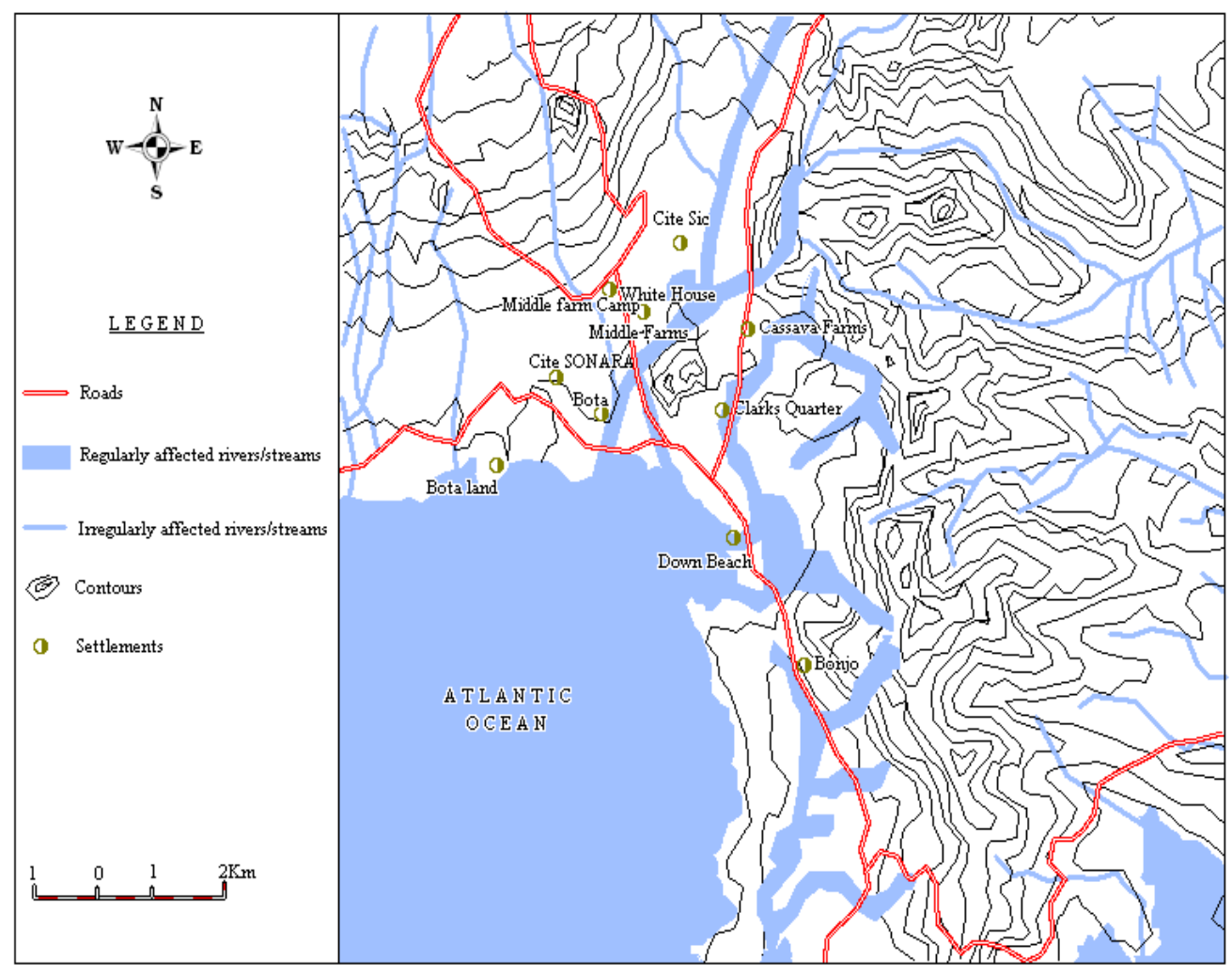

Fig. 3. Regularly flooded rivers and streams in Limbe Source: Adapted from the Map of Limbe, NIC Yaounde, (2016) 
Njilla and Simbo; AJGR, 3(4): 17-34, 2020; Article no.AJGR.60755

Table 2. Perception of the triggering mechanisms of flooding in the different study sites

\begin{tabular}{|c|c|c|c|c|c|c|c|c|c|c|c|}
\hline Indicators & $\begin{array}{l}\text { Cassava } \\
\text { Farms } \\
(\%)\end{array}$ & $\begin{array}{l}\text { Lumpsum } \\
\text { (\%) }\end{array}$ & $\begin{array}{l}\text { Church } \\
\text { Street } \\
(\%)\end{array}$ & $\begin{array}{l}\text { Clerks } \\
\text { quarters } \\
(\%)\end{array}$ & $\begin{array}{l}\text { Mbonjo } \\
(\%)\end{array}$ & $\begin{array}{l}\text { Down } \\
\text { Beach } \\
(\%)\end{array}$ & $\begin{array}{l}\text { Dock } \\
\text { yard (\%) }\end{array}$ & $\begin{array}{l}\text { Motowoh } \\
(\%)\end{array}$ & $\begin{array}{l}\text { Mawoh } \\
\text { (\%) }\end{array}$ & $\begin{array}{l}\text { Mabeta } \\
(\%)\end{array}$ & $\begin{array}{l}\text { Average } \\
(\%)\end{array}$ \\
\hline Nature of topography & 53.33 & 60.00 & 26.66 & 33.33 & 13.33 & 20 & 26.66 & 40 & 33.33 & 40 & 34.66 \\
\hline Nature of rainfall & 66.66 & 73.33 & 53.33 & 46.66 & 33.33 & 26.66 & 40 & 46.66 & 53.33 & 46.66 & 48.66 \\
\hline Soil type & 20 & 13.33 & 20 & 13.33 & 0 & 0 & 0 & 0 & 0 & 0 & 6.67 \\
\hline Drainage conditions & 60 & 66.66 & 53.33 & 66.66 & 53.33 & 26.66 & 33.33 & 20 & 20 & 13.33 & 41.33 \\
\hline Increasing population & 80 & 73.33 & 86.66 & 53.33 & 53.33 & 46.66 & 40 & 60 & 53.33 & 46.66 & 59.33 \\
\hline Deforestation & 60 & 53.33 & 13.33 & 6.66 & 13.33 & 33.33 & 33.33 & 40 & 46.66 & 46.66 & 34.66 \\
\hline $\begin{array}{l}\text { Human encroachment } \\
\text { on river channel }\end{array}$ & 80 & 80 & 73.33 & 80 & 26.66 & 20 & 13.33 & 26.66 & 20 & 26.66 & 44.66 \\
\hline $\begin{array}{l}\text { Inadequacy / } \\
\text { narrowness of drains }\end{array}$ & 40 & 46.66 & 80 & 86.66 & 66.66 & 33.33 & 40 & 26.66 & 0 & 0 & 42.00 \\
\hline $\begin{array}{l}\text { Reclamation and } \\
\text { draining of wetlands }\end{array}$ & 80 & 86.66 & 100 & 100 & 100 & 100 & 100 & 80 & 73.33 & 86.66 & 90.67 \\
\hline $\begin{array}{l}\text { Uncontrolled waste } \\
\text { disposal }\end{array}$ & 26.66 & 40 & 33.33 & 33.33 & 33.33 & 13.33 & 6.66 & 13.33 & 13.33 & 20 & 22.93 \\
\hline Poor urban governance & 26.66 & 13.33 & 40 & 26.66 & 20 & 13.33 & 26.66 & 33.33 & 26.66 & 20 & 24.66 \\
\hline Total / Average (\%) & $\begin{array}{l}593.31 \\
(53.94) \\
\end{array}$ & $\begin{array}{l}606.63 \\
(55.15) \\
\end{array}$ & $\begin{array}{l}597.97 \\
(52.72) \\
\end{array}$ & $\begin{array}{l}(546.62 \\
(49.70) \\
\end{array}$ & $\begin{array}{l}413.33 \\
(37.57) \\
\end{array}$ & $\begin{array}{l}333.33 \\
(30.33) \\
\end{array}$ & $\begin{array}{l}359.97 \\
(32.72) \\
\end{array}$ & $\begin{array}{l}386.64 \\
(35.15) \\
\end{array}$ & $\begin{array}{l}339.97 \\
(30.97) \\
\end{array}$ & $\begin{array}{l}346.63 \\
(30.90) \\
\end{array}$ & \\
\hline
\end{tabular}


Table 3. Average flood height and duration for different quarters in Limbe for 2010 and 2019

\begin{tabular}{|c|c|c|c|c|c|}
\hline \multirow[t]{2}{*}{ Quarters } & \multicolumn{2}{|c|}{ Flood height (cm) } & \multicolumn{2}{|c|}{ Duration of flood (hours) } & \multirow[t]{2}{*}{ Comments } \\
\hline & 2010 & 2019 & 2010 & 2019 & \\
\hline Cassava Farms & 110 & 120 & 7 & 9 & Very severe \\
\hline Motowoh & 100 & 115 & 5 & 7 & Very severe \\
\hline Down Beach & 80 & 86 & 5 & 7 & Very Severe \\
\hline Church Street & 80 & 95 & 2 & 5 & Severe \\
\hline Lumpsum & 75 & 85 & 4 & 5 & Severe \\
\hline Mbonjo & 40 & 46 & 2 & 4 & Moderate \\
\hline Mabeta New Layout & 40 & 45 & 1 & 1 & Moderate \\
\hline Mawoh & 30 & 33 & 1 & 2 & Moderate \\
\hline Dock Yard & 30 & 36 & 1 & 4 & Moderate \\
\hline Clerks Quarters & 30 & 35 & 1 & 3 & Moderate \\
\hline
\end{tabular}

Source: Field work 2010 and 2019

The city is drained by rivers like the Limbe River and Djenguele River which flow through the heart of the city. Limbe is built on the drainage basin of these water courses and since independence these water courses have suffered from mounting pressure from human activities. Wetlands have also been drained and reclaimed for settlement. This is the case of Clerk Quarters (66.66\%), Lumpsum Quarters $(66.66 \%)$ and Cassava Farms (66\%) where most of the houses have been constructed on reclaimed wetlands and flood plains. The respondents of these quarters also noted that the water table is high and the depths of the rivers are shallow, which make the drainage conditions conducive for flooding. Plate 1 shows the flooded Djenguele River around Lumpsum Quarters. Some settlements in Limbe have been constructed on a drainage basin with rivers which are flooded regularly during the rainy season. This is the case with the Djenguele River where houses have been constructed along its banks leading to flooding in quarters like Church Street.

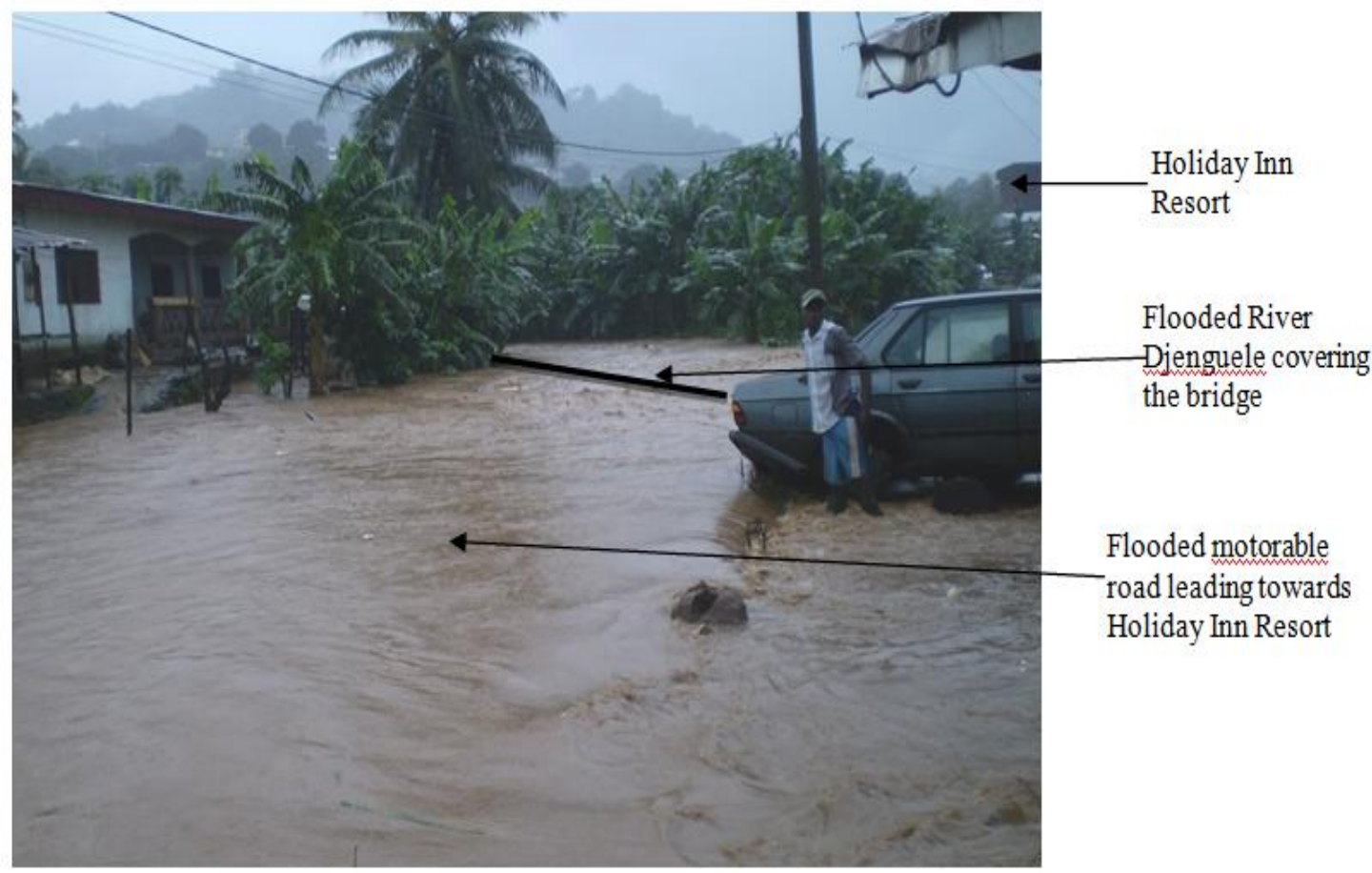

Plate 1. Flooded Djenguele River around Lumpsum Quarters Source: Field work (2019) 


\subsubsection{Nature of topography}

Fig. 4 shows how the nature of the relief of Limbe. The nature of topography of Limbe has a role to play as far as flooding is concerned. The eastern section of the city of Limbe is flanked by a chain of volcanic cones extending from the ocean to Bonadikombo. These cones rise to different heights such as Towe, $362 \mathrm{~m}$; Mile Two, $890 \mathrm{~m}$; Caterpillar Hill $76 \mathrm{~m}$; Coconut Island, 46.5 m; Ambas Bay areas, $152 \mathrm{~m}$; Mabeta New layout, $295 \mathrm{~m}$; Mawoh $153 \mathrm{~m}$ (Buh, 2009). Cassava Farms and Lumpsum for instance are located in a depression surrounded by these volcanic cones such as Animal farms and Unity quarter hills. Any high intensity rainfall leads to floods as runoff rapidly flows from these surrounding slopes to the densely settled areas like Cassava Farms and Lumpsum causing sporadic floods. Inhabitants of these quarters perceive the nature of topography as being the trigger mechanisms of flooding. From Table 4, $53.33 \%$ and $60 \%$ of the respondents of Cassava
Farms and Lumpsum respectively, perceive the nature of topography to be the main triggering mechanism of flooding in Limbe.

\subsubsection{Soil type}

The soil type of Limbe is a mixture of clay, tuffs and scoria. Clay and tuffs are mostly found in low lying areas such as Cassava farms, Clerks quarters, Down Beach and Motowoh. These soils have a high water retention capacity while scoria is mostly found in the volcanic cones with low water retention capacity. Thus when rain falls, water easily drains as through-flow from these cones to the low lands which worsen the situation, making the area vulnerable to flooding. For most of the time, the ground is permanently moist and the rain that falls generally does not infiltrate but rather flows on the surface as overland flow. Only about $20 \%$ of the total population sampled in Lumpsum and Church Street hold that soil type is responsible for flooding.

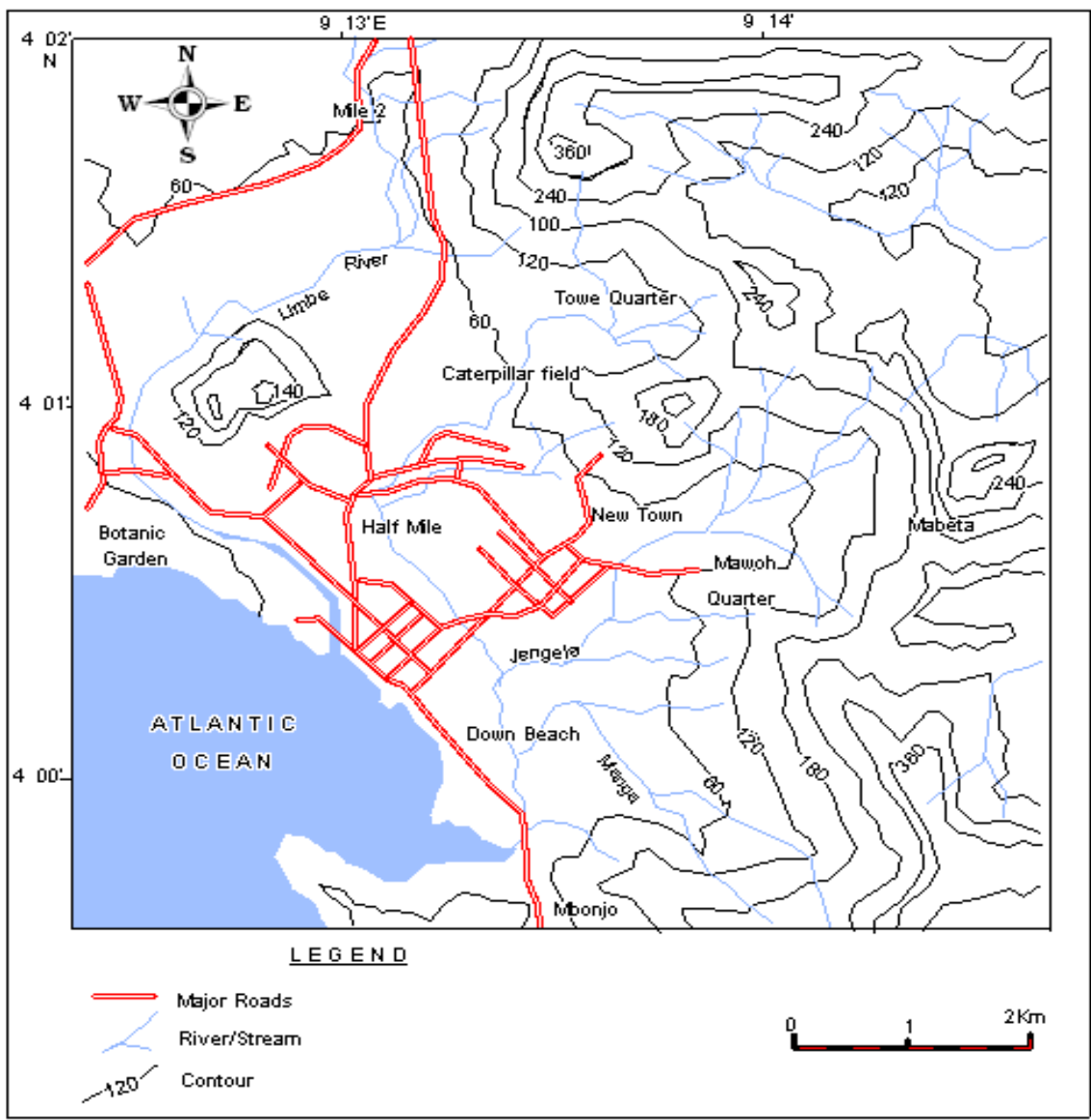

Fig. 4. The topography of Limbe

Source: Adapted from the Map of Limbe, NIC (2016) 


\subsection{Anthropogenic (Human) Factors}

\subsubsection{Reclamation and draining of wetlands}

The reclamation and draining of wetlands around the Limbe Old and New market areas, Manga William's Avenue and Clerks quarter is perceived to have been responsible for flooding in Limbe. This is as a result of rapid population growth that is exerting pressure on land and water resources. The wetlands which ought to act as storm buffers are reclaimed for the construction of houses, thus the proven beneficial ecological service of wetlands in floods mitigation is neglected. $86.66 \%$ of respondents in Clerks quarters, $80 \%$ in Church Street and $66.66 \%$ in Mbonjo are of the opinion that flooding is as a result of the reclamation and draining of wetlands. Sites such as Mbonjo, Down Beach and Dock Yard were initially wetlands which have been transformed into settlement areas. Therefore, the rapidly growing population and the increase in the demand for housing have forced the inhabitants to construct houses in these wetland areas. Plate 2 shows that settlements which are constructed on reclaimed wetlands in Clerks quarters are affected by flooding.

\subsubsection{Increasing population}

Respondents perceived increasing population as one of the triggers of flooding in some quarters of Limbe. Increasing population was accompanied by the construction of houses and infrastructure.
Houses were constructed within the drainage basin and along water courses, resulting in the modification of the stream channels through narrowing of the channel and elimination of tributaries. This is especially the case with the Djenguele River whose course has been greatly modified by man and has consequently made settlements along this river course such as Cassava Farms, Lumpsum Quarters, Church Street and Down Beach, more susceptible to inundation during the rainy season and therefore have experienced persistent flooding over the years. Analysis from Table 2 reveals that $80 \%$ of the respondents in Cassava Farms, $73.33 \%$ in Lumpsum, $86.66 \%$ in Church Street and 60\% in Motowoh, perceive increasing population to be one of the major causes of flooding. This is so because the population of Limbe has been growing very rapidly. For instance, in 1976, the population of Limbe stood at 27,000 inhabitants; 44,561 in 1987 and 118,210 as of November 2005 (Bureau central des recensement et des etudes de population, 2009). Furthermore, responses from interview recount that the increase in population which was followed by the construction of houses and other infrastructures led to an increase in paved surfaces. These paved surfaces in areas like Clerks quarters, Church Street and Motowoh inhibit infiltration and encourage runoff which increases the risk of flooding in these neighbourhoods. Some recorded flood episodes include the floods of 1989, 1991, 2000, 2001, 2005 and 2010 which caused severe damages in these areas.
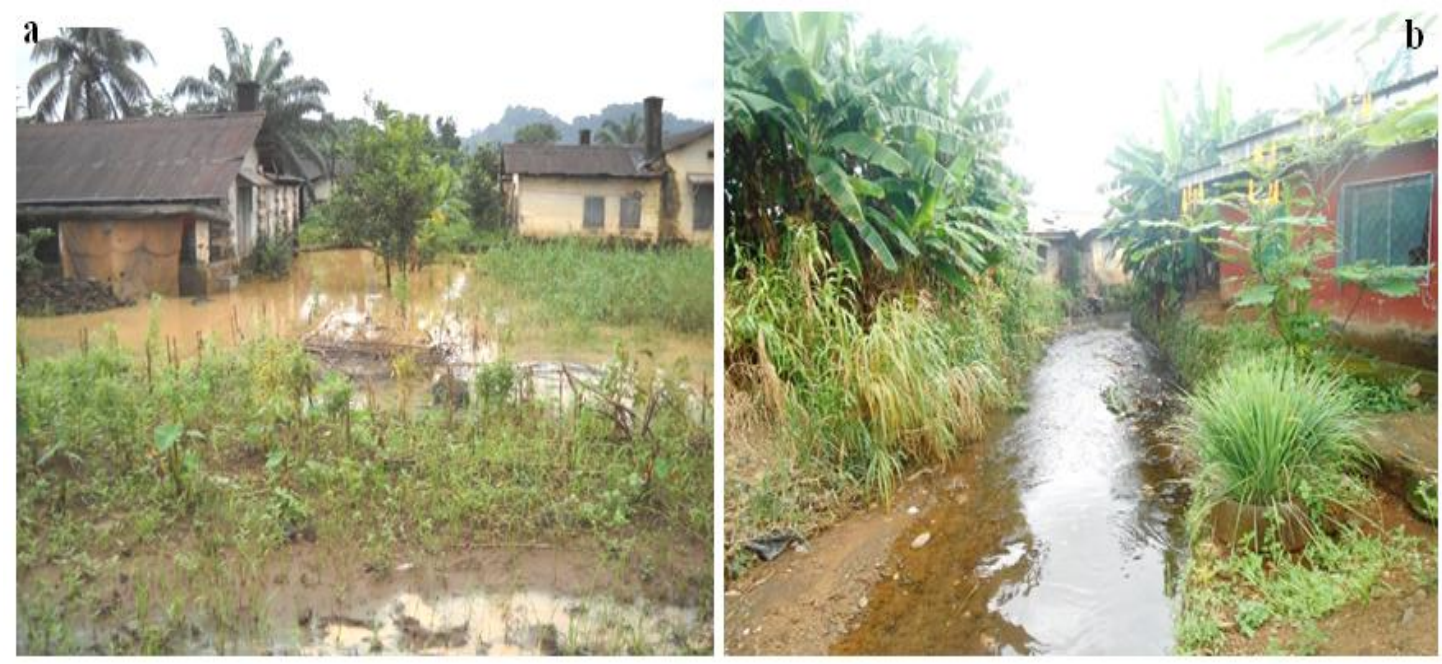

Plate 2. Settlements constructed on reclaimed wetlands (a) Clerks Quarters in 2010 and (b) Lumpsum in 2019

Source: Fieldwork (2010 \& 2019) 


\subsubsection{Human encroachment on the river channel}

Human encroachment on the river channel is also perceived as one of the triggers of flooding in Limbe. The rapid increase in population and the increase in the demand for housing, results in anarchical construction especially along the river channel, consuming part of the river channel, causing the river to meander slowing down its speed and resulting to flooding. Findings revealed that $80 \%$ of respondents in Lumpsum, Clerks quarters, Cassava Farm; and $73.33 \%$ of respondents in Church Street blame human encroachment on the river channel for causing flooding. Field observations showed that some houses are constructed across river channels, partially blocking the normal flow of streams or runoff. This is the case in quarters like Cassava Farms, Church Street, Down Beach and Mbonjo. In Lumpsum, especially part of the Holiday Inn Resort, has been constructed over the Djenguele River channel. Some people deliberately reclaim part of the river by building their homes along river channels, thus colonizing part of the natural river course. These leave no doubt that the forced constriction of the river channel within the urban milieu is perceived as one of the major factors that provoke flooding. Plate 3 shows human encroachment on the river channel in Down Beach.

\subsubsection{The inadequacy / narrowness of drains}

The inadequacy / narrowness of drains is also perceived as one of the triggering mechanisms of flooding in Limbe. This is further compounded by clogging of drains by polythene and debris especially non-biodegradable wastes. All the respondents in quarters like Church Street, Clerks quarters, Mbonjo, Down beach and Dockyard; $86.66 \%$ in Mabeta and Lumpsum; 80 in cassava Farms and Motowoh were of the opinion that the inadequacy/narrowness of drains is responsible for flooding. $90.70 \%$ of the total population sampled in all the study sites, perceived flooding to be triggered by the inadequacy/narrowness of drains.

There is complete absence of drains in many quarters in the city of Limbe such as Cassava Farms, Lumpsum, Motowoh, Mawoh and the Down beach area. An analysis of drains in Limbe is shown on Table 4.

Table 4 indicates dimensional values and effectiveness of drains in the city of Limbe which have been assessed to establish their relationship with flooding. The general trend drawn from the table indicates that all the drains have not been effective in handling the runoff generated in Limbe. This is evident from the fact that the drains are capable of handling $45.38 \%$ of runoff generated in areas where drains exist as shown on Table 4. When taking into consideration the width and depth of the drains with regards to the quantity of runoff, it can be seen that the capacity of the drains are low in relation to the volume of runoff. Field observations show that some of the drains are narrow and others filled with debris. The level of thickness of debris in the drains determines the effectiveness of the drains in handling the quantity of runoff especially during the rainy

Table 4. Dimensional values and effectiveness of drains in the city of Limbe

\begin{tabular}{|c|c|c|c|c|c|}
\hline Quarters & & $\begin{array}{l}\text { Width of } \\
\text { storm drains } \\
\text { or runoff } \\
\text { channels }(\mathrm{cm})\end{array}$ & $\begin{array}{l}\text { Depth of } \\
\text { drain } \\
\text { (cm) }\end{array}$ & $\begin{array}{l}\text { Thickness } \\
\text { of debris } \\
\text { in drains } \\
\text { (cm) }\end{array}$ & $\begin{array}{l}\text { Percentage } \\
\text { effectiveness } \\
\text { of drains (\%) }\end{array}$ \\
\hline \multirow[t]{2}{*}{ Church Street } & Right drain & 52 & 62 & 20 & 67.74 \\
\hline & Left drain & 52 & 62 & 23 & 62.90 \\
\hline Gardens from Half & Right drain & 50 & 50 & 28 & 44 \\
\hline Mile & Left drain & 50 & 50 & 26 & 48 \\
\hline Manga William's & Right drain & 60 & 60 & 25 & 58.33 \\
\hline Avenue & Left drain & 60 & 60 & 29 & 51.70 \\
\hline Clerks Quarters from & Right drain & 57 & 72 & 38 & 47.22 \\
\hline Cow Fence & Left drain & 50 & 50 & 32 & 36 \\
\hline Clerks Quarters from & Right drain & 50 & 50 & 35 & 30 \\
\hline PC Down Beach & Left drain & 120 & 50 & 41 & 18 \\
\hline \multirow[t]{2}{*}{ Down Beach } & Right drain & 50 & 50 & 32 & 36 \\
\hline & Left drain & 50 & 65 & 36 & 44.71 \\
\hline Mean $=\Sigma^{x} / 12$ & & 58.41 & 56.75 & 30.41 & 45.38 \\
\hline
\end{tabular}



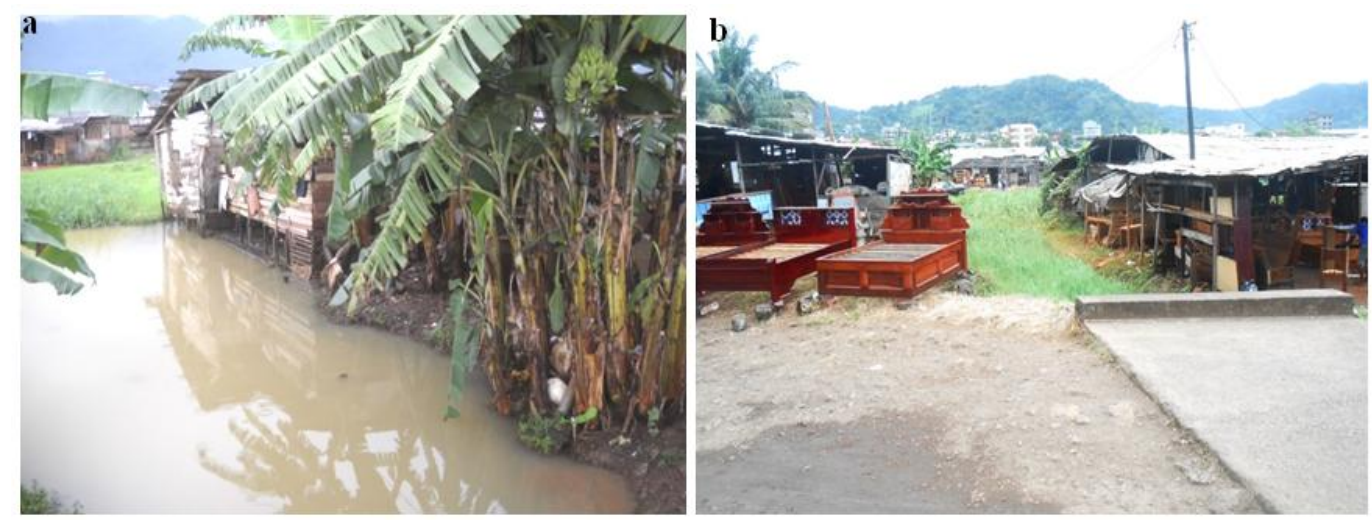

\section{Plate 3. Human encroachment on the river channel in Clerks' Quarters in (a) 2010 during the rainy season and (b) 2019 during the dry season Source: Fieldwork (2010; 2019)}

season. Field measurements revealed that most drains have not been emptied and cleared of debris. This acts as an impediment to the freeflow of runoff in the drains, consequently increasing the magnitude of floods. Localities like Clerks quarters and Down Beach which usually record catastrophic flood events experienced severe floods in 2010 , as a result of drains that were blocked by debris and also due to the fact that some of the drains are very narrow.

Furthermore, certain areas like Lumpsum, Cassava Farms, Mawoh Quarters, Motowoh Quarters, Mbonjo and Dockyard where there are no drains, record heavy flood damages of property every year. Drains which could have contained the runoffs are completely absent in these quarters. Consequently runoffs from the hillocks of these areas usually flood the adjacent settlements. Flooding is thus perceived to be triggered by the inadequacy of drains.

\subsubsection{Deforestation}

Human interventions on the natural environment also increased the severity and frequency of natural hazards like deforestation in the hills around Limbe leading to accelerated runoff and consequently flooding during the rainy season. Deforestation on the Mabeta Hills, Mile Two, Towe and Limbe ridges is also perceived as a trigger mechanism of flooding in the city of Limbe. The eastern section of the city of Limbe is flanked by a chain of volcanic cones extending from the ocean to Bonadikombo. As a result of increasing quest for land for human settlement, the forests on these volcanic cones have been cut down. Consequently, the rate of infiltration of rainfall has been reduced while runoff has been enhanced. Table 2 indicates that about $60 \%$ of respondents in Cassava Farms, $53.33 \%$ in Lumpsum and $40 \%$ in Motowoh perceive flooding to be triggered by deforestation. Cassava Farms and Lumpsum for instance are located in a depression surrounded by these deforested volcanic cones such as Unity Quarter and Animal Farms Hill. Deforestation on these hills is thus perceived to have triggered flooding in these quarters.

\subsubsection{Poor urban governance}

Poor urban governance has a role to play as far as flooding is concerned in the city of Limbe. Poor urban governance by the municipal administration which is very lukewarm, allows people to take environmental laws into their hands by degrading the environment with little or no sanctions, is also perceived as one of the causes of flooding in Limbe. Respondents interviewed say field control exercises carried out by town planning officials is ineffective. This is because there is no mechanism to ensure that laws passed are effected. Basic building codes are not respected by the population especially those constructing along river channels like in Mawoh and Motowoh quarters. The demolition exercises carried out in flood and other disaster prone areas has not been completely successful as most people still go back to the demolished houses, renovate the and continue to live in without any sanction. $40 \%$ of respondents in Church Street, $33.33 \%$ in Motowoh, $26.66 \%$ in Cassava Farms, Clerks quarters and Dock yard, perceive poor urban governance as one of the trigger mechanisms of flooding in Limbe. 
Increasing population, deforestation, human encroachment on river channel, inadequacy/narrowness of drains, reclamation and draining of wetlands, uncontrolled waste disposal and poor urban governance are some of the anthropogenic factors that were perceived as being the trigger mechanisms of flooding in some localities in the city of Limbe. Among these factors, the inadequacy / narrowness of drains was perceived as being the most important trigger mechanisms of flooding.

\subsubsection{Uncontrolled solid waste disposal}

The uncontrolled nature of solid waste disposal in some parts the city of Limbe is also perceived as one of the causes of flooding. $40 \%$ of respondents sampled in Lumpsum, 33.33\% in Clerks quarters, Church Street and Mbonjo; and $26.66 \%$ in Cassava Farms are of the view that flooding in triggered by uncontrolled nature of solid waste disposal in the quarters. People dump domestic waste indiscriminately. This is especially the case with road side vendors like those roasting maize, plantains, fish and those selling other items that dump their waste in the storm drains. This blocks storm drains in areas like Church Street, Mbonjo and the Half Mile area, preventing the free flow of runoff. Traders in the Church Street market area also dump waste carelessly, which blocks drains and stream channels. Waste disposal in rivers like the Djenguele River leads to siltation and suffocation of the river channel, causing flooding in quarters like Cassava Farms and Mbonjo; where people empty their dust bins in the nearby rivers like the Djenguele River. Some do it with the intention that the river will carry away the waste; meanwhile this instead leads to the blockage of some river channels, causing flooding. But with the advent of HYSACAM in Limbe which takes charge of waste disposal, the situation has been put under control since dust bins have been made available in all quarters and are emptied daily by the company. In summary, the anthropogenic factors are significantly related to lack of flood governance; poor environmental governance and poor city governance in general.

\subsubsection{Testing of Hypothesis: Flooding in Limbe is perceived to be triggered by prolonged rainfall}

Chi Square $\left(x^{2}\right)=\frac{\Sigma(\mathrm{O}-\mathrm{E})^{2}}{\mathrm{E}}$

$E=134 / 6=22.33$

$\mathrm{df}=(\mathrm{N}-1)=6-1=5$; $\mathrm{df}=5$; Level of significance $=0.990$

Table $x^{2}$ value $=0.554 ;$ Calculated $x^{2}=9.45$

At a degree of freedom of 5 and a level of significance of 0.990 , the calculated $x^{2}$ values is 9.45 and the table $x^{2}$ value is 0.554 . The calculated $x^{2}$ value 9.45 is greater than the table $x^{2}$ value 0.554 , the hypothesis is accepted since prolonged rainfall is perceived to be one of the trigger mechanisms of flooding in Limbe.

The main triggering mechanism of flooding in the city of Limbe has been perceived to be the inadequacy / narrowness of drains in some quarters in Limbe. This is evident from Table 2 which indicates that over $90.70 \%$ of respondents in all the study sites are of the opinion that the inadequacy/narrowness of drains is the most important trigger mechanism of flooding in the city of Limbe. The results from hypothesis testing revealed that prolonged of rainfall is one of the trigger mechanisms of flooding. Other factors perceived to be trigger mechanisms of flooding include physical factors such as: nature of topography, soil type and drainage conditions; while the human factors on the other hand include: increasing population, deforestation, human encroachment on river channel, reclamation and draining of wetlands, uncontrolled waste disposal and poor urban governance. A combination of these factors contributes to trigger flooding in Limbe.

Table 5. The Chi Square analysis was employed to test this hypothesis

\begin{tabular}{llllll}
\hline Categories & $\begin{array}{l}\text { Observed } \\
\text { frequency (O) }\end{array}$ & $\begin{array}{l}\text { Expected } \\
\text { frequency (E) }\end{array}$ & $\mathbf{O}-\mathbf{E}$ & $\mathbf{( O - E ) ^ { 2 }}$ & $\begin{array}{l}\boldsymbol{\Sigma}(\mathbf{O}-\mathbf{E})^{2} \\
\mathbf{E}\end{array}$ \\
\hline Civil servants & 25 & 22.33 & 2.67 & 7.12 & 0.31 \\
Students & 22 & 22.33 & -0.33 & 0.10 & 0.00 \\
Technicians & 20 & 22.33 & -2.33 & 5.42 & 0.23 \\
Traders & 230 & 22.33 & 7.67 & 58.82 & 2.57 \\
Layman & 26 & 22.33 & 3.67 & 13.46 & 0.60 \\
Street vendors & 11 & 22.33 & -11.33 & 128.36 & 5.74 \\
\hline Total & 134 & & & 213.1 & 9.45 \\
\hline
\end{tabular}




\section{DISCUSSION}

Findings revealed that the major areas affected by flooding in Limbe correspond to the low-lying area. These include Lumpsum, Cassava Farms, Church Street, Clerks Quarters, Mawoh Quarters, Motowoh Quarters, Down Beach, Mbonjo and Dockyard. Due to the proximity of the city to the coast and the low-lying nature of the settlements, the area is susceptible to flooding episodes. These findings are in line with those of Buh [3], Aka et al. [7], Lambi et al. [8], and Kometa and Lambi [9], who corroborated the fact that flooding is Limbe is triggered by the nature of rainfall, the topography and the unstable nature of the slopes due to human settlements.

The findings also revealed that a greater proportion of the respondents perceived inadequacy / narrowness of drains as the most important triggering mechanism of flooding in Limbe. Other important factors included poor urban governance, uncontrolled waste disposal, reclamation and draining of wetlands, and natures of rainfall. The factors such as soil type, drainage conditions, human encroachment on the river channel were perceived to be triggering mechanisms but of a lesser extent. These findings are in line with those of Buh [2], Buh [3], and Buh and Aka [10].

Findings also indicated that the respondents' perception of the triggering mechanisms of flooding consisted of both natural and anthropogenic factors. The natural factors were the nature of topography, nature of rainfall, soil type and drainage conditions. The anthropogenic factors on the other hand included: increasing population, deforestation, human encroachment on river channel, inadequacy / narrowness of drains, reclamation and draining of wetlands, uncontrolled waste disposal and poor urban governance. These findings are in line with those of Buh [3], Lambi [5], Fogwe [6], Kometa and Lambi [9], Buh and Aka [10] and Mosima [11].

\section{CONCLUSION}

The city of Limbe is very sensitive and strategic because of the type of physical characteristics that determines its existence. Because of the commanding role that it plays in the economy of the country, it has attracted a lot of human attention in recent years because there is a high influx of population that adds to the high growth situation of the town provoking mounting pressure on the land and with poor urban governance, floods have become a recurrent hazard especially in the $21^{\text {st }}$ century where climate change is manifesting in a very capricious manner in the humid tropics. As temperatures continue to rise, there is a likely tendency for rising sea level and enhanced convective precipitation to occur in this city resulting in repeated occurrence of floods. During each flood event, it is the marginal community that suffers most. This represents the group of poor urban dwellers who are living in flood prone zones such as valleys, wetlands, marshes and hill slopes, with little or no flood prevention measures. It can therefore be said that a greater proportion of respondents in all the 10 study sites sampled that is $90.70 \%$, perceive the inadequacy/narrowness of drains to be the most important trigger mechanism of flooding in Limbe. Furthermore, hypothesis testing revealed that prolonged rainfall is an important trigger mechanism of flooding in Limbe. However, other perceived trigger mechanisms of flooding in the city of Limbe include increasing population, deforestation, human encroachment on river channel, reclamation and draining of wetlands, uncontrolled waste disposal and poor urban governance. This study has made valuable contributions with respect to urban flush flooding, river morphology and drainage contours.

\section{RECOMMENDATIONS}

The following measures are recommended to mitigate future floods in Limbe based.

\subsection{Recommendations Based on Hardware or Infrastructure Development}

The putting in place of surveillance posts for flood risk zone monitoring and communication could be set up. This needs to be done since the flooding occurs unannounced. This is because it is important for the municipal administration to put surveillance posts to monitor flooding. This reflects the views of flood victims who perceive flooding to be triggered by poor urban governance.

Strict building codes should be implemented which prohibits people from building at unsafe distances from the river channel and from disposing of domestic sewage into the rivers. It will go a long way to help mitigate flooding in Limbe especially in areas where flooding is perceived to be triggered by human 
encroachment on the river channel. These areas include Church Street, Lumpsum, Clerks quarters and all other quarters located along river courses.

Drains and bridges should be constructed with widening ends and not with tapering ends. Such is an application of geomorphology and hydrology to city engineering and will go a long way to mitigate flooding. This will be a very wise venture to undertake especially in quarters where flooding is perceived to be triggered by the inadequacy and narrowness of drains such as Church Street and Clerks quarters. Furthermore, drains should be constructed in quarters where there are no drains like Lumpsum, Cassava Farm, Dock yard, Mawoh and Motowoh. This is because the cry of the people in these quarters is that, drains should be constructed to help mitigate flooding.

Periodic sensitization programs should carried out on flood abatement strategies when there is a flood should be done through the use of the mass media and in the educational curriculum. Such sensitization programs can help educate the people on flood disaster preparedness. This can be done through the use of local radio stations in Limbe such as Ocean City Radio, Eden Radio and Eternity Gospel Radio since these radios cover the entire town.

A participatory approach towards flood control should be used. This entails municipal administration and the local people concerned to be involved in designing flood control measures. Such a participatory approach to flood management will lead to long lasting solutions to the problems of flooding in Limbe.

Develop risk maps, update these periodically and disseminate them to decision makers, the general public and the communities at risk. Such a study can be very relevant because it will help people to know their level vulnerability to flooding and will facilitate conception and designing of appropriate flood management strategies.

\subsection{Recommendations Based Software or Public Awareness}

on

There is need to put in place public awareness systems, media advocacy and curriculum development on urban environmental management particularly with respect to infrastructural development and the abatement of floods in Limbe. This can be incorporated in a programme on disaster risk management and human safety.

There is a clarion call for good flood governance, good city governance, good municipal governance, improvement of flood forecasting and warning, contingency planning, role of media and awareness raising.

Finally, there should be the respect of existing laws in place, as well as their compliance and enforcement by the competent authorities and at various levels of government. This could be done through raising public awareness.

\section{CONSENT}

As per international standard or university standard, respondents' written consent has been collected and preserved by the author(s).

\section{ACKNOWLEDGEMENT}

The authors are thankful and grateful to the numerous respondents who provided primary and secondary data that were invaluable in conducting in this study.

\section{COMPETING INTERESTS}

Authors have declared that no competing interests exist.

\section{REFERENCES}

1. United Nations Development Programme (UNDP) Reducing disaster risk: A challenge for development. A global report. United Nations Development Programme, Bureau for Crisis Prevention and Recovery. New York: Oxford University Press; 2004.

2. Buh WG. Potential Risk and Resettlement Areas in Limbe, Cameroon. Applied Research Grants Programme - Young Researcher's Project Brief - Round 2 (2005-2006) 2028CMR. 2007;1-2.

3. Buh WG. Geographic information systems based demarcation of risk zones: The case of the Limbe Sub-Division - Cameroon. Journal of Disaster Risk Studies. 2009;2(1): 54-70.

4. Asangwe CK. The Douala coastal lagoon complex, Cameroon: Environmental issues. In Administering Marine Spaces: International Issues. FIG publication No 36, 
2006 Copenhagen, Denmark. 2006;134147.

5. Lambi CM. The problems of floods in urban Yaounde. Annals from the Faculty of Letters and Social Sciences, University of Yaounde I, Series, Sciences Humanities. 1989;5(2): 175-190.

6. Fogwe ZN. Mitigating and managing regional geo-environmental hazards within a decentralisation transition in Cameroon. Journal of Human Ecology. 2010;30(3):87195.

7. Aka FT, Ubangoh R, Ntepe N, Ateba B. The June 2001 catastrophic landslides and floods in Limbe, Southwest Province. Unpublished report to IRGM. 2001;14.

8. Lambi CM, Kometa SS, Fombe LF. Environmental Hazards and Landuse planning for sustainable development, The Limbe unstable coastal region, Cameroon. Department of Geography, University of Buea, Cameroon; 2004.

9. Kometa SS, Lambi CM. The Limbe geomorphological high risk problematic environment: An alternative landuse paradigm. African Journal of Social Sciences. 2010;1(2).

10. Buh WG, Aka FT. Enhancing resilience against floods in the Lower Motowoh community, Limbe, Southwest Cameroon. Disaster Prevention and Management; 2018. Project: Satreps NyMo.

DOI: 10.1108/DPM-06-2018-0193

11. Mosima E. Floods continue to hit Yaounde. Cameroon Tribune; 2007.

(c) 2020 Njilla and Simbo; This is an Open Access article distributed under the terms of the Creative Commons Attribution License (http://creativecommons.org/licenses/by/4.0), which permits unrestricted use, distribution, and reproduction in any medium, provided the original work is properly cited.

Peer-review history:

The peer review history for this paper can be accessed here: http://www.sdiarticle4.com/review-history/60755 